\title{
Article
}

\section{Banking from Leeds, not London: regional strategy and structure at the Yorkshire Bank, 1859-1952}

Larson, Mitchell Jonathan, Ward, Karen and Wilson, John F. Available at http://clok.uclan.ac.uk/3259/

Larson, Mitchell Jonathan ORCID: 0000-0002-5506-0815, Ward, Karen and Wilson, John F. (2010) Banking from Leeds, not London: regional strategy and structure at the Yorkshire Bank, 1859-1952. Accounting, Business \& Financial History, 20 (2). pp. 117-133. ISSN 0958-5206

It is advisable to refer to the publisher's version if you intend to cite from the work. http://dx.doi.org/10.1080/09585206.2010.485744

For more information about UCLan's research in this area go to http://www.uclan.ac.uk/researchgroups/ and search for < name of research Group>.

For information about Research generally at UCLan please go to http://www.uclan.ac.uk/research/

All outputs in CLoK are protected by Intellectual Property Rights law, including Copyright law. Copyright, IPR and Moral Rights for the works on this site are retained by the individual authors and/or other copyright owners. Terms and conditions for use of this material are defined in the policies page.

\section{CLoK}

Central Lancashire online Knowledge www.clok.uclan.ac.uk

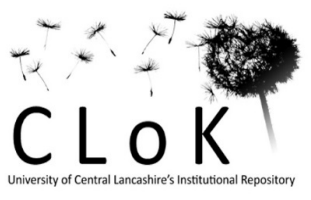


*Corresponding author. Email: mjlarson@uclan.ac.uk

\title{
Banking from Leeds, not London: regional strategy and structure at the Yorkshire Bank, 1859-1952 ${ }^{1}$
}

\author{
Mitchell J. Larson ${ }^{\mathrm{a}^{*}}$, Karen Ward ${ }^{\mathrm{b}}$, John F. Wilson ${ }^{\mathrm{c}}$ \\ ${ }^{a}$ Lancashire Business School, University of Central Lancashire, UK; ${ }^{b}$ Leeds Grammar School, Leeds, \\ UK; ${ }^{c}$ University of Liverpool Management School, UK
}

\begin{abstract}
Industrial philanthropist Edward Akroyd created the Yorkshire Penny Savings Bank in 1859. Despite competition from the Post Office Savings Bank after 1861 and a serious reserve problem in 1911, it sustained his overall strategy to become a successful regional bank. Using archival and contemporary sources to build on recent scholarship illustrating how savings banks were integrated into local economies and the complementary roles of philanthropy and paternalism, we analyse an English regional bank's strategy, including an assessment of strategic innovation, ownership changes, and management structure. This will demonstrate that the founder's vision continued, even though the 1911 crisis radically altered both strategy and structure.
\end{abstract}

Keywords: penny savings banks; Edward Akroyd; regional strategy and structure; Yorkshire Penny Bank; philanthropy; Midland Bank

\section{Introduction}

Like many contemporary savings banks, what is today known as Yorkshire Bank plc began in an industrial region in the north of England under the patronage of a wealthy textile magnate, Edward Akroyd (Webster 1987). Headquartered in Leeds rather than London, the Bank reached out to a range of customers living in all corners of Yorkshire, attracting a larger number of depositors than all of the other joint stock banks in that county (Crick and Wadsworth 1936). Although Ó Gráda has claimed that up to the mid-nineteenth century British savings banks 'bypassed the really poor, its main beneficiaries being better-off savers', Akroyd's institution not only attracted a significant number of low-income depositors but also retained them as loyal customers. The business grew as a result of the core vision of its founder, using a variety of strategies that were adjusted over time, even though in 1911 and 1952 two serious crises affected the ownership structure. The Bank’s appeal derived from 
customer knowledge that it was embedded in the regional community and run by well-known and trusted locals, rather than being yet another bureaucratic extension of financial control from distant London. Indeed, the distinction of being a locally-owned and managed bank set the Yorkshire Bank apart from its competitors, becoming a valuable marketing asset in itself which management actively nurtured as a means of projecting the image of a responsible local bank in which all types of customers could have complete faith. As we shall see, that faith proved well-placed for generations of depositors for whom the Bank offered the most credible financial services available. Having started as a manifestation of industrial paternalism, Yorkshire Bank plc consequently became one of Britain's most important regional banks, appealing not only to depositors from the working population, but also those with larger incomes who were attracted by the returns offered by such institutions.

This paper is divided into four sections. The first relates how the bank emerged in the 1850s, by illustrating how Edward Akroyd strove to instil values like thrift into his company's workforce, as well as contextualising the institution's emergence in the legal and financial environment. The second section examines the organisation of the Bank and explains why it grew rapidly up to the Edwardian years, when a major crisis in 1911 significantly affected its ownership structure. As we shall see in the third section, it had become such an important feature of the regional banking system that major figures in the UK banking sector felt obliged to implement a restructuring plan. In 1952, another crisis required a syndicate of banks to fashion a recovery programme that laid the basis for postwar expansion. Finally, our concluding remarks assess the degree of continuity in the core strategic vision as articulated by the Bank's founder and draw some preliminary conclusions about patterns found in the available data. Unfortunately, the availability of Yorkshire Bank archival material is poor, forcing the authors to employ a range of alternative sources in lieu 
of more direct evidence and leading us to make strong suggestions on a series of issues rather than come to definitive conclusions.

\section{Akroyd, industrial paternalism and savings banks}

Recent academic literature on savings banks, and especially penny savings banks, has tended to focus more on Scotland and Ireland rather than England or the UK overall (Maixé-Altés 2009; Ó Gráda 2003; Ross 2002). The one major contribution to the field is now decades old (Horne 1947), while the history of a major state institution, the Post Office Savings Bank, is still to be written. ${ }^{2}$ Penny banks, even more than savings banks, tended to open and close relatively quickly during the nineteenth century, in part due to scandals in similar banks elsewhere, as well as income instability on the part of their primary customer base, the working population, which was badly affected by both under-employment and unemployment throughout this era. While some large retail and commercial banks (Barclays, Midland, Lloyds) have institutional histories (Ackrill and Hannah 2001; Holmes and Green 1988; Winton 1982), a survey of recent literature on regional banking in England yields little of note, even though savings banks have a much older pedigree which reach back to experiments conducted by various religious groups and philanthropists in the late eighteenth century (Horne 1947). The major surge in creating savings banks occurred after 1807, resulting in state intervention by 1817 as a means of laying down basic regulations on their constitution and operation. By 1820, 512 savings banks existed across Britain, most of which had been established by prominent local people keen to assist the working population develop greater independence. This philosophy proved popular, because by 1841, when 553 savings banks existed, over 841,000 depositors had paid in almost $£ 24.5$ million (Horne 1947). Most of these operations stayed small in scale, limiting the opportunities of full-time staff to develop the concept more widely. On the other hand, within major industrial districts, savings banks had become an established feature of working class life. 
Closely linked to this trend was the emergence of the penny savings bank in England (Horne 1947, 182-7). Sir Charles Sikes established the first English penny bank in Hull in 1849, prompting a significant surge in their popularity. After publishing a pamphlet on this concept, Sikes also started another in Huddersfield in 1850, leading him later to encourage the Chancellor of the Exchequer, William Gladstone, to found the Post Office Savings Bank (Daunton 1985; Yorkshire Bank Archive 1856). Other philanthropists undertook to replicate his initiative in their own communities for a variety of reasons, an excellent example of which is the work of Edward Akroyd. Having inherited, in 1847, an estate worth $£ 300,000$ from his industrialist father, Edward Akroyd significantly expanded the family's woollen factories in Halifax, indicating how this firm was a major contributor to the region's emergence as Britain’s principal woollen and worsted manufacturing centre. ${ }^{3}$

While one could say much more about both the Akroyd business and the industrial communities that clustered around its factories (Bretton 1949; Hanson 1940), the key dimension from our perspective is the link between these activities and the establishment of a penny savings bank. Akroyd believed that Yorkshire was a ripe market for a bank willing to assist the growing working population to develop greater financial independence. At the same time, low wages and immature social legislation did not protect workers from the business cycle; poverty and the workhouse instilled fear among factory labourers because a trade downturn could result in unemployment followed by destitution. Factory-owners were also still struggling to instil time-discipline into their workforces, reflecting fundamental control issues that occupied management constantly (Joyce 1980; Wilson 1995). To combat these challenges, as early as 1852 the Woodside Penny Savings Bank had been formed by Edward Akroyd within his Copley factory community. Based in the pay office of the Bowling Dyke mill, the bank had 600 depositors by March 1853 who had paid in over £819, Akroyd having encouraged all employees to donate one penny per week from their earnings into the Bank. 
He printed maxims like A Year of Carefulness Will Save Many a Year of Care on paying-in books, reinforcing the point that it was the individual's responsibility to provide for his/her own welfare. By 1855, the bank had moved into the much larger Haley Hill site, where Akroyd converted a building originally intended to house a Baptist chapel to act as its base (Yorkshire Bank Archive 1856). Although Akroyd discovered that many young depositors tended to withdraw their savings between Easter and Whitsuntide, and most adults withdrew their savings at the beginning of November and May, when the half-yearly rent payment was due (Yorkshire Bank Archive 1856), overall the new institution was clearly proving popular.

To Akroyd, the Bank formed an intrinsic part of an overall strategy to inculcate into his workforce those virtues that he felt would stand them in good stead over the long-term. As he wrote, when advocating the creation of a larger scheme covering all of West Yorkshire:

Unless, like a working bee [the worker] can lay up beforehand a sufficient store of honey against the benumbing frost of sickness or the coming winter of old age, the vision of a starving wife and family.... may become a sad reality (Yorkshire Bank Archive 1856).

Many nineteenth century industrial paternalists would have heartily agreed with this philosophy, a point firmly substantiated by the work of Ross $(2001$; 2002) on Scottish savings banks. Indeed, industrial paternalism was an extremely common motivation for establishing such businesses with the specific emphasis on teaching lessons of thrift and saving to the disadvantaged people both in their employ and more generally. Ross (2001; 2002) has illustrated that Scottish philanthropists in Glasgow and elsewhere formed penny banks in the poorest parts of the city and attempted to persuade the residents of the importance of saving, including and especially children who were perceived to be ripe for such valuable lessons, a strategy the Yorkshire Penny Bank would utilise towards the end of the century. Religious enthusiasm to assist the lower classes combined with a more secular industrial paternalism to result in organisations like penny banks, with which workers could provide for their own needs without the embarrassment of taking charity directly. 
Glasgow penny banking experienced rapid growth: by the end of the 1850s over thirty penny banks operated in the city, while that number had doubled by the time the Post Office Savings Bank opened just three years later in 1863 (Ross 2002, 26). Whereas Glasgow held a large and densely-concentrated working population who might desire savings accounts, thereby emulating the middle classes around them, one might argue that Akroyd aspired to even greater heights in his attempt to provide banking for the lower classes across the entire county of Yorkshire. The Glaswegian penny banks fell mostly within the confines of the city, making it much easier to inspect and regulate their activities (Ross 2002, 29). The successful extension of bank branches to the more remote areas of Yorkshire and to the poorer parts of Glasgow demonstrated an appreciation among the working population of the banks' facilities, and shows that workers could and would save prudently when the opportunity was offered to them, with or without the lessons in 'thrift' that philanthropists such as Edward Akroyd sought to teach.

Just like many of his contemporary counterparts, Edward Akroyd consequently concerned himself with the welfare of his workers, recognizing that enhanced employee loyalty arose from a growing sense of financial security. He even provided small pensions for those who left his employ due to old age, given his growing conviction of the inadequacy of the poor law relief system (Yorkshire Bank Archive 1860). Above all, though, he believed in self-help, with the penny savings bank as the principal manifestation of this philosophy.

One of the greatest influences on Akroyd was a pamphlet published by Charles Sikes on the penny savings bank concept. He was also heavily influenced by another contemporary publication by Countess Spencer, entitled East and West, which offered practical solutions to helping the poor to help themselves, leading him to devise an ambitious scheme capable of relieving working class poverty across the West Riding (Yorkshire Penny Bank 1872; 
Yorkshire Bank Archive 1888). Akroyd referred to the qualities of the working men of the region:

The working men of the West Riding are naturally shrewd, provident, industrious, and imbued with a noble spirit of independence ... they manifest a disposition to save money and to lay up provision against sickness and old age (Yorkshire Bank Archive 1856).

As Akroyd believed that this form of 'self help' could aid in conquering poverty, in May 1856 he proposed the creation of a West Riding Working Man’s Provident Society and Penny Savings Bank, offering a clear vision for the new institution which he pursed with missionary zeal. Although his initial efforts ran into local resistance at various levels, slowing the early progress of the new institution (such as when he struggled to amalgamate his new provident society with similar existing bodies in the region, and when news of the intended Post Office Savings Bank diminished interest in Akroyd's venture), Akroyd and his supporters worked hard to extend the new operation's geographical spread (Yorkshire Penny Bank 1872). However, realising that the provident society branch could not compete with the friendly societies that had existed for several decades, this branch was merged with the Mutual Provident Alliance Society (Joint Stock Companies' Journal, 21 March 1900; Yorkshire Penny Bank 1872). This allowed him the opportunity to focus on the development of what he renamed the West Riding Penny Savings Bank. Such was the success of this small operation that in May 1859 it was re-launched as the West Riding of Yorkshire Penny Savings Bank. As its name indicates, Akroyd was trying to extend the bank's remit regionally, with a head office in Leeds and a new slogan, From One Penny Upwards.

An important point to make about this move is the changing legislative environment in which the Bank emerged. Until the 1850s, savings banks had been extending across most of the British Isles, especially in highly-concentrated urban industrial regions. However, concern about their shaky financial base led the Chancellor of the Exchequer, William Gladstone, to reform the system, establishing the Post Office Savings Bank in 1861 as a means of providing government backing for the small-scale saver (Daunton 1985). The 
number of private savings banks consequently declined, to just 230 by 1901, compared to over 530 in 1841, holding funds of $£ 58.2$ million for 1.65 million depositors. Over the same period, the Post Office Savings Bank opened 8.8 million accounts and took in $£ 140$ million (Holmes and Green 1988; Horne 1947, 389-91). Another of Gladstone's reforms was the 1863 Savings Bank Act, which forced private savings banks to seek certification as a trustee savings bank and agree to tightly-regulated investment and deposit strategies. This could have severely proscribed the opportunities open to Akroyd's new venture, especially as savers switched in significant numbers to the Post Office Savings Bank.

Fundamental changes of this kind were to have a major impact on Akroyd's strategy, because they persuaded him to imitate the many regional commercial banks that existed in Yorkshire and other northern counties. Indeed, while the West Riding of Yorkshire Penny Savings Bank's origins owed much to paternalistic aspirations, its development from the early 1860s strongly reflected Akroyd's desire to develop a full range of services still aimed at the vast majority of the population who had been neglected by traditional joint stock banks, namely, those colloquially known as 'the great unbanked'. In response to claims that the Post Office Savings Bank would eliminate the need for penny savings banks, Akroyd stressed that his government-backed rival served only large towns and villages. The West Riding Penny Savings Bank would consequently be accessible to all who needed the facility, including those who lived in remote communities (Horne 1947, 188), adding considerably to its popular appeal. It also explains why, in 1871, Akroyd registered his venture as a joint stock company limited by guarantee, renaming it the Yorkshire Penny Bank ${ }^{4}$ (Sellers 1899). In one bold stroke, this change avoided three potential pitfalls for savings banks: the limitations on the amount which could be saved by a depositor in a single year; the minimum deposit requirement of one shilling which then applied to savings banks; ${ }^{5}$ and it widened investment choices for the Bank as an institution (Hartley 1975, 85). One must stress, though, that while 
Akroyd's savings bank operated de jure as a joint stock company, de facto it was still regarded by both its management and customers as a savings bank, driven by the mission to inculcate thrift into the psyche of the Yorkshire working classes. In simple terms, this was an institution based on trusteeship, which was philanthropic in character yet utilised legal and financial techniques that facilitated a longevity and geographical dispersion that were unusual in English savings banks, the bulk of which were short-lived and localised. No other English savings bank would appear to have imitated the Yorkshire Penny Bank, a fact that helps to explain their failure to survive the onslaught from the Trustee Savings Bank.

Crucially, no share capital was floated at the time of this reconstitution, indicating how Akroyd and his immediate successors insisted on the pursuit of a vision laid down in the 1850s, namely, that the Bank existed to help 'the great unbanked'. Another feeling that Akroyd exploited was a widespread distaste amongst Northern businessmen of the much wealthier London financial institutions, a sentiment that at times extended to those regional joint stock banks that were frequently linked to an institution based in the capital city. In general, though, as we shall see later, it was the working population that remained the focus of the Akroyd institution's activities, building a customer base that was unrivalled amongst Yorkshire banks.

\section{Organisation, strategy and expansion}

In developing the Yorkshire Penny Bank, Akroyd proposed to establish an extensive network of branches controlled by a central supervisory body. As the president of this central committee needed to be a man of high standing, Akroyd found a number of men able and willing to serve in this capacity. ${ }^{6}$ In Akroyd's pyramidal structure, there were two or more vice presidents and five permanent trustees nominated by fifteen guarantee managers, all of whom came from local business communities. Presidents of the district committees served as ex officio members of the central committee, which in turn nominated treasurers to each 
district. In order to extend the geographical coverage, branches were opened in towns and villages under the supervision of the district committees. Polling districts fixed the boundaries for each district, with local committees taking responsibility for setting the amount of cash held by each branch, subject to the approval of the central committee. The district committee also approved the establishment of new branches prior to requesting permission from the central committee. Each district committee was headed by a president and at least five managers, while the district presidents became members of the district committee (Yorkshire Bank Archive 1859).

As the local branches had day-to-day contact with customers, they represented the 'grass roots' of the Bank. Each branch operated under the management of a president, two or more managers, an actuary and an auditor, all of whom constituted the branch committee. ${ }^{7}$ Business could not take place at any branch unless the actuary, a manager, and an auditor were present (Yorkshire Penny Bank 1872). The actuaries served as cashiers and thus received deposits on behalf of the Bank, remitting any surplus cash to the district treasurer before the following deposit night. As the actuaries had direct responsibility for the money held by each branch, they had to be men of good character who were well respected in the community. The branch managers, typically men of position and influence in the neighbourhood, instilled confidence in depositors because they were obliged not only to donate $£ 5$ to the Bank and make an annual subscription of at least ten shillings, but also render gratuitous service throughout their tenure (Yorkshire Penny Bank 1872, 12). While any manager could be appointed to the branch committee, only a guarantee manager could serve on the district and central committees (Yorkshire Bank Archive 1859).

(Insert Table 1 about here) 
The institution's first phase of expansion demonstrated that the organisation of the Bank worked effectively in accommodating the robust growth recorded in Table 1. Starting in May 1859 as one part-time branch which also functioned as the Head Office, five new branches had been opened within three months. By the end of the year there were twenty-four part-time branches scattered around the West Riding, with roughly 2000 depositors who had placed a total of $£ 23,313$ with the Bank. From these humble origins, as Table 1 reveals, over the following sixty years the Yorkshire Penny Savings Bank expanded impressively, denying the conventional wisdom that this kind of operation was decreasingly attractive. Although much of this success can be traced to the founder's core vision for the business, another crucial factor was the choice of agent who controlled the local branches. As branches arose amidst their potential customers, agents were appointed who were recognised and respected by local people. Choices such as these increased the visibility of the Bank and encouraged trust. Moreover, the majority of actuaries and managers were from the beginning selfsacrificing, for in the early days there was little hope of reward (Sellers 1909, 25). There were so few deposit accounts that the resulting commissions often failed to cover expenses, resulting in bank workers being paid out of the cash available. Each branch committee also had to pay for its first set of books, money that would be raised by donations from local businessmen. Furthermore, Bank employees usually held full-time positions elsewhere, and Bank officials expected them to attend their duties in all weather, on pain of complaints to Head Office (Sellers 1909).

Working for the Bank entailed a degree of personal sacrifice not usually associated with bank employees in more conventional operations (Thomson and Wilson 2006, 69-73). The willingness of its first employees to spend personal money to provide these services reflects a high level of commitment to the principles of its founder. Indeed, observers frequently attributed the Bank's phenomenal success to its management and staff, even if 
local clergymen also used the Bank as an educational and philanthropic agency in order to 'bring them into direct contact with their parishioners' (Sellers 1909, 23). The Keighley Herald (15 June 1894) described the manager of the local branch, Mr. C.W. Tate, as 'a most courteous and attentive manager...if the management of the Keighley branch may be taken as a criterion, there is little wonder at the remarkable progress of the undertaking'.

In the beginning, apart from the Head Office in Leeds, premises used as branches were not solely dedicated to the purpose of banking. Indeed, most branches opened for business one evening per week for one or two hours at a variety of sites, such as Mechanics Institutes, school rooms, church halls, and reading rooms. The logic behind such decisions was quite plain: the Bank commonly operated on pay days or market days, or when obvious local justifications existed for providing banking services. The Bank benefited enormously from branch locations being both familiar and convenient to its customers. Above all, Akroyd wanted Bank branches to be an integral part of each local community, using familiar locations that were convenient, in the knowledge that individuals would come to associate the Bank with key events. This strategy proved so successful that by 1909 H.B. Sellers (1909, 178) could write that branches served 'the needs of the people and invite[d] them to accept the advantages the Institution can offer them by bringing the Bank intimately into their social life, and even to their house doors'. Within a short period of time, the branches covered the needs of virtually all isolated villages in the county (Yorkshire Bank Archive 1959). While as early as the 1860s the central committee realised that the administration costs of so many scattered evening branches were prohibitively high, given the need to pay to transport fulltime staff around the expending network, this structure was retained as a key part of the overall strategy of maintaining contact with the small retail banking customer, especially in remote villages. ${ }^{8}$ The number of evening branches peaked at 955 in 1894, after which the number declined gradually to 687 by 1920 (Yorkshire Bank Archive 1920). This indicates 
that customers still demanded access to the part-time evening branches operated by the Yorkshire Penny Bank, demonstrating both how customers remained loyal to the Bank and the Bank's willingness to persist with operating branches that cost more to run than the amount of money generated from payments received. The success of Yorkshire Bank in reaching out to isolated communities also encouraged imitation around the country by other regional lenders. By 1911, Farrow’s Bank Ltd., based in Brighton, introduced a travelling bank that called at seven or eight villages in Sussex per day. Drawing a parallel with the Yorkshire Penny Bank, the Daily News (29 January 1911) explained that Farrow's Bank hoped to reach potential customers in remote villages that did not possess local banking facilities.

Another dimension of the Bank's location strategy was to extend the network from the West Riding to the rest of Yorkshire. As we have seen, the 1863 Savings Bank Act forced Akroyd to register the company as the Yorkshire Penny Bank. Although, under its original articles, a new branch could only be opened within ten miles of the county borders, this was later relaxed, allowing the establishment of branches all over Yorkshire and its adjoining counties by the 1920s. ${ }^{9}$ The Yorkshire Penny Bank even opened an office in London, reflecting a desire to form attachments to the country's banking centre, yet maintaining its regional character with a headquarters in Leeds (Yorkshire Penny Bank Ltd. 1924).

As the boundaries expanded and the numbers of both branches and customers increased, it became clear that part-time evening branches could be safely reduced as customers in urban areas were then able to patronise full-time, dedicated branches. This helped to reduce costs by decreasing the number of part-time evening branches which occasionally, as we have seen, ran operating deficits. By 1898, twenty-three branches were open every day, and thirty-six sub-branches opened on occasional days. Daily branches had their own dedicated manager and were subject only to the control of head office. Sub- 
branches, on the other hand, were subordinate to the daily branches to which they were affiliated. Akroyd's original control structure thereby survived his death in 1887, albeit at one level removed from the central supervisory committee. By 1909, there were forty-nine daily branches and fifty-eight sub-branches. Thirty of these new branches arose out of evening branches 'by the ordinary natural growth of the continually increasing requirements of business'; some of these were located in the new suburbs built outside the big towns and cities to accommodate the bourgeois classes, indicating a change in the Bank's client base over time (Sellers 1909, 149).

As one newspaper report stated, the Yorkshire Penny Bank, run by 'keen Yorkshiremen', was a concern based on trust. To this end, the investments of the Bank were placed in gilt-edged securities only (Yorkshire Chat, 25 November 1899; Bell 1895). ${ }^{10}$ While these conservative investments occasionally proved inadequate for the level of deposits taken in by the Bank, management always reassured customers of the Bank's stability, a message the local press appeared to accept without question until the 1911 crisis (see below) shook journalists out of their complacency. By publishing the full accounts of the Bank annually down to branch level - an unprecedented level of openness for a bank of any kind in this era - the Bank enjoyed tremendous support and loyalty from the people of Yorkshire. Indeed, it had become so integrated with the local public that by 1909 the Yorkshire Penny Bank directly serviced at least one-fifth of the population of Yorkshire. The Ripon Observer (9 December 1909) referred to its stability, openness, and trust by writing that the Bank stood 'as an honourable symbol, an epitome, of Yorkshire character'. Reflecting their paternalist origins, the branches shared in both the prosperity and the decline of communities, frequently offering help during trade slumps when unemployment was high. For example, in 1870, when Bradford experienced a severe trade slump, the Bank opened a soup centre for depositors in the Bradford Parish Church (Yorkshire Bank Archive 1959). Such actions served not only a 
short-term public relations purpose, but also gave further evidence that the Bank faced local challenges alongside the local population.

The Yorkshire Penny Bank became part of a 'virtuous circle' of success, earning the glowing admiration of some observers during the second half of the nineteenth century. With the aid of dedicated management and workers, the Bank reached out through its comprehensive branch network to the working population of Yorkshire. The Bank's significant business achievements, such as its high levels of market penetration, customer loyalty, and community engagement, won great respect across the country. In an 1895 pamphlet, J. Hyslop Bell enthusiastically endorsed nearly everything the Bank did, quoting both Dr. Samuel Smiles (who commended Akroyd for 'promoting the moral and spiritual welfare of... [those] who have been virtually committed to his charge') and a contemporary bank examiner to offer further testimony of its success as both bank and philanthropic endeavour (Bell 1895, 4, 8-9). In 1900, the Joint Stock Companies Journal commented that, unlike other banks, the Yorkshire Penny Bank had experienced tremendous growth not as the result of amalgamations and absorptions which were typical of more conventional banks at that time (Wilson 1995, 125), but by a constant increase in the volume of business (as recorded in Table 1). The Joint Stock Companies Journal (21 March 1900) attributed this to capable leadership, noting that:

The Yorkshire Penny Bank stands out as a bright example of what can be done by energy and able management, and what a colossal institution can be built from a very small beginning.

By 1905, the Yorkshire Penny Bank challenged the myth reported in the Daily Report (6 March 1905) that 'penny banks do not pay'. ${ }^{11}$ Furthermore, while joint stock banks favoured wealthy customers, the Yorkshire Penny Bank catered to the far more numerous working population, as Table 2 indicates. Although those with less than $£ 200$ in their accounts held just $57 \%$ of total deposits, crucially this group represented $97 \%$ of customers. Furthermore, the Yorkshire Penny Bank held more in deposits than every other joint-stock 
bank operating in Yorkshire, if one compares the information in Table 2 with that collected by Crick and Wadsworth (1936, 239-40). This demonstrates the credibility of Akroyd's initial vision that the Yorkshire working population would benefit from the combination of an extensive regional branch network that was fundamentally sound and stable. In the final years leading up to the First World War, the average amount of each deposit was only slightly in excess of $£ 3$, and the average sum due to each depositor was just under $£ 25$ (see Table 1 data for 1910); therefore the Bank was clearly correct in claiming that it was 'reaching the class of people the bank was intended to reach' (Sellers 1909, 90).

(Insert Table 2 about here)

Some of its initiatives, however, revealed the Bank’s limitations over the long-term. For example, in the late 1860s the Bank publicized its mortgage offerings by announcing loans over $£ 50$ on freehold and copyhold security (Broomhead 1981, 156). From 1874-1881, the Bank offered customers an investment account paying higher than ordinary interest for sums over $£ 50$ on deposit for more than three months. Annual interest of 3.5 per cent could be earned, subject to a notice of withdrawal of one calendar month. The resolution creating these new investment accounts became part of the Articles of Association on 13 January 1874, at which point all 1,998 accounts holding in excess of $£ 50$ were converted into an investment account. However, the investment account scheme became a victim of its own success, because the higher interest rate and its popularity was more than the Bank could afford, forcing its abandonment on 31 December 1881 (Sellers 1899, 25).

In general, while wealthier people paid attention to interest rates offered by the Bank, for working customers the Bank represented a safe and convenient place to save money (Yorkshire Penny Bank 1872, 32). The constitution of the Bank and its widespread operations made regulating the rate of interest during market fluctuations difficult, especially as the 
Bank of England rates occasionally changed from week to week during this period (Clapham 1966). While the Yorkshire Bank strove to keep its own interest rates more stable, by 1895 the cost of running so many small evening branches forced the Bank to consider lowering the interest rate on all deposits from 3 to 2.75 per cent (Clapham 1966; Yorkshire Bank Archive 30 October 1894). ${ }^{12}$ The rapid expansion of the business and the concomitant growth in customer numbers, combined with gradually declining interest rates during the years following the Bank's creation, served to delay the eventual squeeze on the Bank. This combination of new customer acquisition with declining interest rates for savers effectively smoothed out the amount paid by the Bank to its depositors, but depended heavily on the continuation of traditionally low rates of interest. Thus, when rates rose slightly after bottoming in the 1880s, the Bank had to make a decision about the rate of interest it could afford to pay. Proof that these decisions had consequences appeared in the published accounts for 1895, which demonstrated that the amount of money deposited dropped from the previous year by more than $£ 324,000$, as customers sought better returns. The Bank’s overall strategy of targeting the working population in Yorkshire, however, meant that while the amount involved in each transaction was lower, The Bullionist (11 April 1896) could record that the total number of transactions increased, demonstrating that wealthy customers took their money elsewhere, while the Bank's core customers maintained their loyalty. Indeed, the Bank was so successful in generating customer loyalty that the Western Independent (26 March 1905) commented that 'in spite of bad trade, scarcity, unemployment and political unrest, Yorkshire Penny Bank continues to prosper’.

Writing in 1909, Sellers $(1909,179)$ referred to the Yorkshire Penny Bank as a 'Peoples Bank'. Clearly he considered it neither a commercial bank nor a savings bank; by constitution and practices it reflected Akroyd's vision of conducting business to the advantage and convenience of the regional working population. The introduction of business 
accounts was considered 'commercial' and was discouraged in all branches: the directors purposely decided not to venture into the more lucrative sphere of commercial business, although by the 1880s cheque books for small traders had been introduced. Similarly, the Bank shunned open competition for customers. Indeed, one of the factors governing the expansion of the branch network was that a branch should not trespass on another institution's territory, because management believed that 'hostile rivalry results in the lack of success to either party’ (Sellers 1909, 150).

In spite of this approach towards competition, by 1905 it was noted that the Bank was encountering increased rivalry from established commercial banks looking to graft a savings bank department onto orthodox businesses (Investors' Review, 11 March 1905). Some commercial banks began advertising in the windows of their offices and in local newspapers that they would soon be prepared to receive deposits as low as $£ 1$, a strategy intended to 'gather up the savings of the people in any sums of not less than one shilling' (Sellers 1909, 157). The Yorkshire Penny Bank management thought the endeavour was sure to fail, since internal accounting conventions calculated that two-thirds of its own work was unprofitable (Sellers 1909). They tolerated the situation purely because the Bank was not primarily a profit-making institution; it had no shareholders or partners constantly demanding returns on their investment. As Sellers (1909, 38) stated: ‘[Operating without profit] has been done, is being done, and will be done, because the business of the Yorkshire Penny Bank is philanthropy regulated on the lines of security. We ask for no more profit than will keep our doors open'. It was this approach that separated it from most of its important competitors, adding significantly to its strong regional identity as a means of recruiting increased numbers of depositors.

\section{Crisis and change, 1911-1952}


By many criteria, the Yorkshire Penny Bank enjoyed success, especially when one considers the data presented in Tables 1 and 2. By 1911 it served over 615,000 depositors and had approximately £18.2 million on deposit, operating an extensive branch network that helped to build a solid reputation amongst the Yorkshire public. Akroyd could be proud of the way in which his successors had built upon his vision of assisting those who found it challenging to save for difficult times. In 1911, however, the Bank faced the consequences of favouring paternalism over the needs of the banking business, because while senior management pursued Akroyd's vision relentlessly, some issues were ignored. For instance, they devoted relatively little attention to accumulating adequate reserves or making sufficient investments to cover deposits. Indeed, by 1910 only $£ 468,000$ had been allocated to the reserve fund, leaving the Bank vulnerable to a large-scale run on its $£ 18$ million of deposits. An external Midland Bank investigation revealed a deficit of $£ 600,000$ in the reserve account, largely from depreciation in the value of its gilt-edged securities (Holmes and Green 1988, 143-7). The return on Consols consistently underperformed the UK Bank Rate from 1896 until after the First World War (Clapham 1966; Mitchell 1988; Sheppard 1971); by 1911 the Yorkshire Penny Bank had been paying more in interest payments to its customers than it received from its investments (Bell 1895; Sellers 1909). ${ }^{13}$ More general concerns grew within the banking community about savings banks, and thus by extension to penny banks, when two of these institutions experienced severe difficulties at that time: the Charing Cross Bank collapsed due to fraud in 1910, while in 1911 the Birkbeck Bank failed because it had not depreciated its investments properly (Holmes and Green 1988, 144; Horne 1947, 300).

The Yorkshire Penny Bank’s vulnerability began at the turn of the century and came to the attention of Sir Edward Holden, chairman of the Midland Bank, while assessing his bank's prospects for further expansion in the north of England (Crick and Wadsworth 1936, 196-240). Steadily diminishing securities prices combined with continued deposit growth to 
erode the value of the Yorkshire Penny Bank's reserve fund, to such an extent that with over $£ 18$ million on deposit the reserve had sunk to less than $£ 500,000$ (or just $2.77 \%$ ) (Holmes and Green 1988, 144). In view of the collapse of Birkbeck Bank the previous year from precisely the same issue, savings banks around the country came under closer scrutiny. Unable or unwilling to resolve the Yorkshire Penny Bank’s large deficit alone, Holden arranged extensive discussions with the Governor of the Bank of England, Lord Cunliffe. These talks resulted in a rescue package involving eleven of the major commercial joint-stock banks, designed to maintain 'confidence in the banking system' of the country (Clapham 1966, 412; Holmes and Green 1988, 144). The growing importance of the Yorkshire Bank in the north of the country meant that damage to the financial system might have been severe if the Yorkshire Bank failed. The 'bail-out' involved the formation of a new limited company that would issue $£ 1.5$ million in paid-up capital and reserves, while another $£ 900,000$ was raised to cover investment depreciation. Holden's Midland Bank became the major partner in this new syndicate by subscribing $£ 375,000$ (thus receiving two seats on the reconstituted Board of Directors of the Yorkshire Penny Bank), while Barclays, Lloyds, the London Joint Stock Bank and the Union of London and Smiths Bank each invested £187,000 (and received one seat each on the Board); others stood ready to subscribe if necessary. Furthermore, Holden instructed his branch managers in Yorkshire to resist undermining the Yorkshire Penny Bank’s customer base during recapitalization. Further support was given at the onset of the First World War, when the government joined the syndicate as guarantors of the Bank’s deposits and took action to prevent a run on the Bank (Holmes and Green 1988, 145). Only in 1922 was the government released from its pledge, by which time the Yorkshire Penny Bank had recovered sufficiently to start boosting its investment portfolio and provide adequate cover for depositors. 
In hindsight, reviving the Bank represented a highly rational strategy for the syndicate, given the appreciable improvement in performance recorded over the interwar years. Holden's motives for adopting the consortium approach remain subject to conjecture, but given his subsequent behaviour towards the Yorkshire Penny Bank (prohibiting direct competition and enlisting the cooperation of Bank of England Governor Lord Cunliffe) suggests that maintaining customer confidence in banks overall remained central to his thinking. Importantly for the Yorkshire Penny Bank, the core vision originally set in place by Akroyd did not change, because it still acted as a savings institution for working people, rather than a fully-fledged commercial bank. On the other hand, the syndicate moved its headquarters to London, because the new directors who worked for the various member banks resisted travel to Leeds to attend board meetings. Despite this geographical switch, the new board provided largely passive supervision until the 1980s, allowing the existing Yorkshire Penny Bank senior management team based in Leeds to continue to make the key strategic decisions.

During the interwar years, the Yorkshire Penny Bank devoted greater attention to marketing, and since the branch was the first point of contact with the Bank for the majority of customers, great care and attention went into architecture and layout. Indeed, during the 1930s the Architects Department of the Yorkshire Penny Bank received wide acclaim (Reilly 1938). An article in the Bank’s internal publication Staff Notes read: 'Modern conditions and standards call for a different type of building for the conduct of banking business...our Architects Department have designed buildings which are intended to break down old traditions and conform to many of the more modern tendencies of architecture' (Yorkshire Penny Bank Ltd. Staff Committee 1938, 19). Much thinking would appear to have gone into the positioning and spacing of entrance doors, public spaces, counters and desks, while brick buildings with stone dressings provided the external design for the new branches. 
These design and layout changes also reflected the Bank's desire to attract new customers, given that management felt there was too much 'stiffness and false dignity' in these institutions (Yorkshire Penny Bank Ltd. Staff Committee 1924). On the other hand, while the Yorkshire Penny Bank's survival rested on providing the financial services demanded by its customers, the Bank kept these services simple. By the 1920s services included current accounts, chequebooks, and overdrafts granted on approval, while in 1923 the Bank opened a branch in London and both the stocks and shares and foreign departments were transferred there. ${ }^{14}$ For the convenience of its growing base of business customers, the Bank installed night safes at certain branches to enable deposits to be made day and night. Indeed, 'Security and Service' became the motto of the Yorkshire Penny Bank in the late 1920s (Beverley Guardian, 15 November 1930) An Executor and Trustee business also began in 1926; within six years, 15,000 customers had appointed the Bank as executor.

In the 1920s the Bank clearly did not abandon its core customers. Holiday, Savings, and Christmas Clubs came with special Club Cards free of charge, while Housekeeping Accounts also featured (Yorkshire Bank Archive 1920, 11). In 1928, the Yorkshire Penny Bank combined with the London and North Eastern Railway (LNER) to devise a scheme whereby holidaymakers paid into a weekly holiday fund. The Bank held the money and provided interest, while the railway granted a 5\% discount on tickets. A Bank spokesman told the Hull Times (3 November 1928) that the scheme 'showed that the railway company and the banking company, both old institutions, were alive to the requirements of the age'. Railway Travel Departments appeared in certain branches, a liaison that was described as 'an epoch-making event in the history of the railway world and the banking world'. By working with an established company like the LNER, the scheme showed how the Yorkshire Penny Bank continued to be entrenched in the life of working people. 
Even though the Yorkshire Penny Bank underwent tremendous change in the early twentieth century, some elements retained a peculiarly 'Dickensian' aspect. Branch operations, as late as 1906, were often tedious, but procedural changes eased this burden considerably, especially in terms of communicating between branches. Transactions between branches had always been carried out by forwarding a 'Letter of Request' from the general treasurer to the Head Office, often creating severe delays (Sellers 1909, 163). Cash could not be transferred from Head Office to a branch or from one branch to another without involving either the general manager or one of the district treasurers. The general manager immediately before the First World War, H.B. Sellers, regarded these outdated book-keeping techniques as a major problem, forcing him to institute a system for the prompt clearing and exchange of cheques (Sellers 1909, 164). As the Bank handled more business, these problems intensified until the introduction of reforms devised by Sellers in 1908 that facilitated the growth process. This system brought branches into communication with both Head Office and each other, as well as linking the branches directly with the Clearing Agents, creating 'an intercommunicating and cohesive whole' (Sellers 1909, 165). These innovations demonstrate that, up to the syndicate recapitalization in 1911, senior management experimented with both improving the range of services offered to customers and reducing costs in line with Akroyd's paternalist and non-profit mindset. After 1911, given that the London-based board of directors rarely interfered in day-to-day management, they were allowed to continue developing a range of practices that would serve their expanding client base as effectively as possible.

After 1945, as the board feared a recurrence of the security devaluation that followed the First World War, close attention was paid to the Yorkshire Penny Bank’s affairs. Indeed, unsettled post-war economic conditions meant that the Bank's gilt-edged securities again depreciated significantly, causing concern within the syndicate. By 1952 the Bank required 
$£ 1 \mathrm{~m}$ from the syndicate to cover this depreciation. Senior management at the Yorkshire Penny Bank’s largest owner, Midland Bank, were simultaneously considering a more independent approach towards its own business, eschewing all entreaties to participate in cooperative ventures. Consequently, when the Yorkshire Penny Bank needed additional capital in 1952, the Midland Bank refused to subscribe and insisted instead on an investigation into its activities. A radical shift in the Midland's orientation resulted; while the other members of the syndicate agreed to invest up to $£ 1 \mathrm{~m}$ in new equity, a broad reassessment of Yorkshire’s strategy began when Midland sold its shares (Holmes and Green 1988, 218). The Midland Bank had not only brought salvation in 1911 by arranging the rescue syndicate and persuading the government to guarantee the venture during the First World War, but also Sir Edward Holden had insisted that Midland Bank branch managers operating in the north should not undermine the Yorkshire Penny Bank's market position. This 'gentlemen's agreement' preventing direct competition was only terminated in the late 1940s, giving Yorkshire Penny Bank a long period in which they could rebuild their finances.

The strategic reassessment that took place in 1952 marked a watershed in the Yorkshire Penny Bank’s evolution. Having operated as a regional, non-profit, communityoriented savings bank since its creation in 1859, after 1952 it moved into a complete range of banking services as a result of the withdrawal of its principal supporter. Despite this change, management felt secure in both the branch network and its own banking expertise to make this transition, while benefiting from a solid reputation amongst its essentially Yorkshire clientele. Expansion into a full-service bank proved to be a well-timed move, because in the increasingly affluent post-war decades a relatively safe banking environment allowed the Bank to test the new approach. The Bankers' Magazine (January-June 1950) was confident that the Bank could cope with the changes, noting that in the previous 200 years approximately 150 banks had been founded in Yorkshire but 'one only, the Yorkshire Penny 
Bank, survived as a separate entity... To reach a century in such solitary grandeur is in itself something to boast about'.

\section{Conclusion}

It is beyond the scope of this paper to discuss whether the post-1952 management team proved worthy of the confidence expressed in their abilities by the Bankers' Magazine, but it is valuable to re-examine the strategies that helped them win the respect of their counterparts in other institutions. Returning to Akroyd's motivations for establishing the Bank, his strategy of appealing to the working population across Yorkshire succeeded far beyond his original goals. What began as a mechanism for inculcating values of thrift and prudence in his own workforce - for both paternalistic reasons as well as his own self-interest as an employer - exploded in popularity during the decades after its establishment to become a household name in financial services for a large portion of the Yorkshire population. By concentrating his efforts on those typically unable to utilize conventional savings or commercial banks due to minimum deposit requirements, he assisted the poorer classes of society - 'the great unbanked' - to help themselves through practical and realistic banking policies designed specifically for that group. Despite a major recapitalisation in 1911 to replenish reserves rendered insufficient by the Bank's substantial growth and investment depreciation, it appears that the overall approach was sound from the late 1850s through two world wars and into the post-war period.

Recent scholarship tells us that the experiences of savings banks in Scotland and England exhibited broadly similar traits during the nineteenth century and that legislation served to limit the business possibilities open to them: for example, by imposing a maximum amount to be held per depositor (Maixé-Altés 2009, 40-1). These institutions adopted a strategy of consolidating multiple small accounts on behalf of penny banks, charitable societies, and similar bodies. According to Ross (2002), by doing so a savings bank could 
position itself to hold the accounts of the most successful savers as their balances exceeded penny bank limits, enabling them to switch over to a conventional savings bank account. This process of switching 'high-balance' savers from penny banks to savings banks took place throughout the second half of the nineteenth century, offering savings banks an indirect way of expanding their business. Our data also show, however, that a number of Yorkshire Penny Bank savers would have encountered resistance as their balances approached the Savings Bank limits ( $£ 150$ maximum for an individual account) created by legislation earlier in the nineteenth century and confirmed in the 1863 Savings Bank Act.

What Ross' article also demonstrates about the business practices of the Yorkshire Penny Bank is that industrial paternalism was an extremely common motivation for establishing such businesses (Ross 2002, 21, 23; 2001). Akroyd held what he believed to be more significant goals in teaching lessons of thrift and saving to the disadvantaged people both in his employ and eventually across Yorkshire as the Bank's activities expanded. Religious enthusiasm to assist the lower classes combined with a more secular industrial paternalism to result in organisations like penny banks with which workers could provide for their own needs without the embarrassment of taking charity directly. In conclusion, Edward Akroyd accomplished many of his goals with his experimental penny bank. Within twelve years he had expanded the Bank's operations to include banks and branches at multiple sites across the county and registered it as a company limited by guarantee, to evade the depository and investment restrictions placed on savings banks. Within forty years, the Bank operated in nearly one thousand locations in England, centred mostly in the north of the country, and specifically catering to the working population. It had expanded 'organically', rather than through mergers and acquisitions, empowering management to install the same successful formula across the company. Akroyd's basic philanthropy and paternalism continued under subsequent managing directors, who saw themselves as upholding the founder's vision for 
the company. This maintained the Bank’s solid relationship with its customers, leading to

considerable success when measured by numbers of depositors and the strong regional

identity that sustained its performance throughout the twentieth century.

\section{Notes}

\footnotetext{
${ }^{1}$ The authors gratefully thank the editors of the journal and anonymous reviewers for their comments and assistance in preparing this paper.

2 The exception here is Daunton (1985) which provides a valuable insight into this institution.

${ }^{3}$ Improvements included the purchase of Heineman's combing patent (at a cost of £33k) and the Luddenden Foot factory (no dates given, but probably 1840s or early 1850s). See “Edward Akroyd”, Malcolm Bull’s Calderdale Companion online: freepages.history.rootsweb.ancestry.com/ calderdalecompanion/mma26.html. ${ }^{4}$ After the original organisational meeting in 1856, Akroyd collected a guarantee fund for the venture of $£ 2,990$ which supported the Penny Bank in its early days. In addition to this lump sum, guarantors promised an annual subscription of $£ 1915$ s to continue growing the reserve. These contributions are noteworthy because the company did not re-register as a company limited by guarantee until 1871, i.e. more than a decade later.

${ }^{5}$ One shilling equalled 12 pennies in the pre-decimal currency or 5 pence today.

${ }^{6}$ Until 1911, these men were the Hon. Edwin Lascelles (1859-1866), the Marquis of Ripon (1866-1870), Akroyd himself (1870-1880), the Earl of Wharncliffe (1880-1882) and the Earl of Harewood (1882-1911).

${ }^{7}$ The term 'actuary' has had several meanings since the sixteenth century. In the nineteenth century it commonly meant 'one who manages the deposits of a savings bank.' Today's understanding, one who examines statistical mortality tables for insurance purposes, also began in the mid-1800s and endured while other terms, such as clerk, cashier, or teller replaced the term 'actuary' within banks.

${ }^{8}$ The point here is that the Yorkshire Penny Bank management consciously weighed the financial value of closing some part-time branches (thus reducing costs) against the harm to their customers by withdrawing the Penny Bank's services from areas where no other financial institution existed. The Yorkshire Penny Bank management concluded it was more important to provide banking services, however modest, in the many small rural communities with part-time branches even if it cost the institution itself a little more money to do so.

${ }^{9}$ This operational limitation was removed in new Articles of Association following the change of ownership of the Bank in 1911.

${ }^{10}$ Bell insisted that the reserve fund was safe specifically because 'every shilling of [it] was invested in British Consols’, this represented $£ 191,000$ by 1893. As we point out below, however, this was not entirely accurate.

${ }^{11}$ This report also claimed that 'many are the big joint-stock banks which regard the Yorkshire Penny Bank with envy'.

${ }^{12}$ Bank Rate during 1895 was 2 per cent and remained at that level until September 1896, when it rose by 0.5 per cent.

${ }^{13}$ The picture is further complicated by some confusion over where the Bank's investments had been made.

Bell claimed that the entire reserve had been invested in Consols (see above), but published records by the Bank suggest a more diversified portfolio containing investments in Consols, railways, and public utilities such as gas companies.

${ }^{14}$ In the 1930s, new arrangements allowed traveller's cheques to be cashed at banks abroad, which required expertise in overseas transactions which the Yorkshire Penny Bank had not developed internally.
} 


\section{References}

Primary sources

Yorkshire Bank Archive, Leeds.

1856. Proposed Scheme for a West Riding of Yorkshire Provident Society and Penny Savings Bank. London.

1859. The Rules and Regulations of the West Riding of Yorkshire Penny Savings Bank. Leeds. 1860. Report of a Meeting of Magistrates, Clergy, and Gentry, Held in the Philosophical Hall, Leeds, on 17 November 1856, for the Purpose of Establishing The West Riding of Yorkshire Provident Society and Penny Savings Bank. 2nd ed. Leeds.

1888. Halifax Branch of the Yorkshire Penny Bank: Opening of the New Premises. Leeds. 1894, 30 October. Reduction of Interest Rates. Leeds.

1920. Facilities For Thrift. Leeds.

1924. To the Members of Staff (a booklet produced by Head Office, November). Yorkshire Penny Bank Ltd. Staff Committee. Leeds.

1938. To the Members of Staff (a booklet produced by Head Office, October). Yorkshire Penny Bank Ltd. Staff Committee. Leeds.

1959. A Short 'Centenary History' of the Yorkshire Penny Bank. Leeds.

Secondary sources

Bankers’ Magazine. January-June 1950.

Beverley Guardian. 15 November 1930.

The Bullionist. 11 April 1896.

Daily News. 29 January 1911.

Daily Report. 6 March 1905.

Hull Times. 3 November 1928.

Investors' Review. 11 March 1905.

Joint Stock Companies Journal. 21 March 1900.

Keighley Herald. 15 June 1894.

Ripon Observer. 9 December 1909.

Western Independent. 26 March 1905.

Yorkshire Chat. 25 November 1899.

Ackrill, M. and L. Hannah. 2001. Barclays: the business of banking, 1690-1996. Cambridge: Cambridge University Press.

Bell, J.H. 1895. Our era. No. 2. In praise of the Yorkshire Penny Bank. Darlington: J. Dodd.

Bretton, R. 1949. Colonel Edward Akroyd. Transactions of the Halifax Antiquarian Society: 61-100

Broomhead, L.J. 1981. The great oak: a story of the Yorkshire Bank. Leeds: Yorkshire Bank. Clapham, S.J. 1966. The Bank of England: a history. Vol. 2. Cambridge: Cambridge University Press. (Orig. pub. 1944.)

Crick, W.F. and J.E. Wadsworth. 1936. A hundred years of joint-stock banking. London: Hodder \& Stoughton.

Daunton, M.J. 1985. Royal Mail: The Post Office since 1840. London: Athlone Press.

Hanson, T.W. 1940. Jonathan Akroyd's account books. Transactions of the Halifax Antiquarian Society: 127-55.

Hartley, W.C.E. 1975. Banking in Yorkshire. Clapham, Yorkshire: Dalesman. 
Holmes, A.R. and E. Green. 1988. Midland: 150 years of banking business. London: Batsford.

Horne, H.O. 1947. The history of savings banks. Oxford: Oxford University Press.

Joyce, P. 1980. Work, Society and politics: the culture of the factory in later Victorian England. Brighton: Harvester Press.

Maixé-Altés, J.C. 2009. Enterprise and philanthropy: the dilemma of Scottish savings banks in the late nineteenth century. Accounting, Business \& Financial History 19, no. 1: 39-59.

Mitchell, B.R. 1988. British historical statistics. Cambridge: Cambridge University Press.

Ó Gráda, C. 2003. Savings banks as an institutional import: the case of nineteenth-century Ireland. Financial History Review 10, no. 1: 31-55.

Reilly, C.H. 1938. In The Banker, August.

Ross, D. 2001. 'Between philanthropy and entrepreneurship: two Scottish savings banks in the early nineteenth century' in Entrepreneurship in business and research. Essays in honour of Håkan Lindgren. Eds. M. Henrekson, M. Larsson, and H. Sjögren. Stockholm: Institute for Research in Economic History.

Ross, D. 2002. 'Penny Banks' in Glasgow, 1850-1914. Financial History Review 9, no. 1: 2139.

Sellers, H.B. 1899. Memoranda from a note book on the Yorkshire Penny Bank. 1st ed. Leeds: Samuel Moxon and Son.

Sellers, H.B. 1909. Memoranda from a note book on the Yorkshire Penny Bank. 3rd ed. Leeds: Samuel Moxon and Son.

Sheppard, D.K. 1971. The growth and role of UK financial institutions 1880-1962. London: Methuen.

Wilson, J.F. and Thomson, A. 2006. The making of modern management: British management in historical perspective. Oxford: Oxford University Press.

Webster, E. 1987. Edward Akroyd (1810-1887) \& A Brief History of James Akroyd \& Son. Transactions of the Halifax Antiquarian Society: 19-45.

Wilson, J.F. 1995. British business history, 1720-1994. Manchester: Manchester University Press.

Winton, J.R. 1982. Lloyds Bank, 1918-1969. Oxford: Oxford University Press.

Yorkshire Penny Bank 1872. The Yorkshire Penny Bank: A Narrative [compiled by the secretary]. With an introduction by Edward Akroyd, M.P. London: Longmans, Green \& Co.

Yorkshire Penny Bank Ltd. 1924. A Prosperous and Progressive Institution For The Promotion of Thrift: Vide Financial News. 
Table 1. Number of depositors and amount on deposit.

\begin{tabular}{|c|c|c|c|}
\hline Year & $\begin{array}{c}\text { Depositors } \\
\text { (rounded) }\end{array}$ & $\begin{array}{c}\text { Amount on Deposit } \\
\text { (to nearest } £ \text { ) }\end{array}$ & $\begin{array}{l}\text { Estimated } \\
\text { Average Holding } \\
\text { per Depositor }(£)\end{array}$ \\
\hline 1860 & 2,000 & $£ 23,313$ & $£ 11.65$ \\
\hline 1870 & 46,000 & $£ 229,609$ & $£ 4.99$ \\
\hline 1880 & 120,600 & $£ 1,115,008$ & $£ 9.25$ \\
\hline 1890 & 280,500 & $£ 5,021,169$ & $£ 17.90$ \\
\hline 1900 & 550,000 & $£ 12,840,902$ & $£ 23.34$ \\
\hline 1910 & 740,000 & $£ 18,542,280$ & $£ 25.06$ \\
\hline 1920 & 950,000 & $£ 29,575,686$ & $£ 31.13$ \\
\hline
\end{tabular}

Sources: Sellers (1899); Yorkshire Bank Archive (1920). 
Table 2: Yorkshire Penny Bank account-holders in 1911.

\begin{tabular}{|r|c|c|c|}
\hline $\begin{array}{c}\text { Number of } \\
\text { accounts }\end{array}$ & $\begin{array}{c}\text { Range of account } \\
(£)\end{array}$ & $\begin{array}{c}\text { Amount due to } \\
\text { depositors }\end{array}$ & $\begin{array}{c}\text { Average holding } \\
\text { per group }\end{array}$ \\
\hline 595,379 & Under $£ 200$ & $£ 10,356,470$ & $£ 17.39$ \\
\hline 18,058 & $£ 200-£ 700$ & $£ 5,927,716$ & $£ 328.26$ \\
\hline 1,042 & $£ 700-£ 1,000$ & $£ 845,903$ & $£ 811.81$ \\
\hline 663 & $£ 1,000-£ 2,500$ & $£ 820,716$ & $£ 1,237.88$ \\
\hline 62 & $£ 2,500-£ 5,000$ & $£ 163,166$ & $£ 2,631.71$ \\
\hline 10 & $£ 5,000-£ 10,000$ & $£ 63,924$ & $£ 6392.40$ \\
\hline 2 & Over $£ 10,000$ & $£ 22,207$ & $£ 11,103.50$ \\
\hline $\mathbf{6 1 5 , 2 1 6}$ & & $\mathbf{E 1 8 , 2 0 0 , 1 0 2}$ & $£ 3,217.56$ \\
\hline
\end{tabular}

Source: Broomhead (1981, 42). 